\title{
Järjestötyöntekijä huolehtii osaamisestaan
}

\author{
Järjestöjen työntekijät kehittäisivät osaamistaan \\ nykyistäkin aktiivisemmin, jos työpaikkojen käytännöt \\ sen sallisivat. Määräaikaiset työntekijät suosivat \\ erilaisia oppimisen tapoja kuin vakituiset.
}

\section{$\mathbf{y}$}

KOLMANNEN SEKTORIN MERKITYS työnantajana on kasvanut voimakkaasti Suomessa ja muissa Euroopan maissa 1990-luvulta lähtien (esim. Anheier ym. 2012). Syynä on sosiaalipoliittinen kehitys: järjestöillä on entistä tärkeämpi rooli palvelujen tuottajina.

Palveluja toteuttamaan on tarvittu runsaasti esimerkiksi terveydenhoitoalan ammattilaisia ja järjestötyöhön ja vapaaehtoisten ohjaamiseen perehtyneitä ihmisiä. Tehtävät ovat muuttuneet yhä monimutkaisemmiksi ja niihin liittyvät riskit ovat kasvaneet, joten vapaaehtoiset kaipaavat yhä enemmän ohjausta. (Esim. Carmel \& Harlock 2008; Merrill \& Safrit 2003).

Merkittävä syy kolmannen sektorin työnantajaroolin kasvulle on myös se, että hankerahoitusta hyödynnetään toiminnassa entistä enemmän. Kilpailu rahoituksesta on lisännyt työn epävarmuutta ja määräaikaisten työntekijöiden osuutta. Nykyisin noin joka neljäs kolmannen sektorin työntekijä työskentelee määräaikaisessa työsuhteessa sekä Suomessa että esimerkiksi Isossa-Britanniassa. (Chartered Institute of Personnel and Recruitment 2014; Ruuskanen ym. 2013.) Muutokset asettavat osaamiselle uusia vaatimuksia, ja viimeaikainen työolotutkimus osoittaa, että halua kehittää osaamista on eri alojen työpaikoilla enemmän kuin tosiasiallisia mahdollisuuksia (Kauppinen ym. 2013).

Suomalaisia järjestötyöpaikkoja on tutkittu toistaiseksi verrattain vähän. Tietoa esimerkiksi osaamisen kehittämisen käytännöistä ei ole aiemmin kerätty. Tässä artikkelissa tutkimusongelmana on se, 


\section{J ÄRJESTÖT OVAT MUIHIN}

ORGANISAATIOIHIN

VERRATTUNA

\section{ERITYISLAATUISIA}

TYÖYMP ̈̈RISTÖJ $\ddot{A}$, SILL $\ddot{A}$

NIIT $\ddot{A}$ JOHDETAAN JA

NIISS ̈̈ TYÖSKENNELLÄÄN

YHTEISTYÖSS $\ddot{A}$

VAPAAEHTOISTEN KANSSA.

miten järjestöissä työskentelevät vakituiset ja määräaikaiset työntekijät kehittävät osaamistaan. Vastauksia etsitään seuraaviin kysymyksiin: 1) Eroavatko määräaikaisessa ja vakituisessa työsuhteessa olevien työntekijöiden osaamisen kehittämisen tavat ja haasteet toisistaan? 2) Onko järjestön rakenteellisilla tekijöillä (koko, toimiala) yhteyttä osaamisen kehittämiseen?

Määräaikaisten ja vakituisten työntekijöiden valinta vertailukohteiksi juontuu paitsi määräaikaisen työn lisääntymisestä kolmannella sektorilla myös sektorin nopeasta ammattimaistumisesta. Tarve kehittää työntekijöiden osaamista lisääntyy koko ajan, mutta kun määräaikaisten työntekijöiden osuus samanaikaisesti kasvaa, yhtälö voi olla vaikea. (Anheier ym. 2012; Opetus- ja kulttuuriministeriö 2010). Aiempien tutkimusten mukaan määräaikaiset työntekijät osallistuvat henkilöstökoulutukseen vakituisia työntekijöitä harvemmin (esim. Akgündüz \& van Huizen 2015; Booth ym. 2002).

\section{KOLMAS SEKTORI ON POIKKEUKSELLINEN TYÖNANTAJA}

Julkisen ja yksityisen sektorin väliin sijoittuvaa, pääosin yhdistyksistä ja säätiöistä muodostuvaa kolmatta sektoria on tutkittu työnantajana muita sektoreja vähemmän. Kolmannen sektorin asema ja yhteiskunnallinen merkitys vaihtelee maittain, mutta yhteistä on se, ettei se tavoittele voittoa. Varat ohjataan omaan perustoimintaan.

Lisäksi organisaatiot ovat yksityisiä (non-governmental) siinä mielessä, että ne eivät voi olla täysin riippuvaisia valtiollisesta rahoituksesta (esim. Ketola 2015, 42). Toisaalta monille järjestöille julkinen tuki on elintärkeä. Tuen antajalla voi olla omia vaatimuksiaan toiminnalle, esimerkiksi sen kohderyhmille (Heikkala 2001, 44).

Tässä artikkelissa kolmannella sektorilla tarkoitetaan järjestöjä. Vaikka järjestöt mielletään ensisijaisesti vapaaehtoisten toimintaympäristöksi, niiden merkitys on kasvanut viime vuosikymmeninä myös palkkatyön näkökulmasta. Palkkatyötä ovat lisänneet hankerahoituksen käyttö sekä sektorin tuottamien hyvinvointipalveluiden laajentuminen.

Ruuskasen työryhmineen (2013) tekemän laajan selvityksen mukaan työnantajana toimivien järjestöjen määrä on kaksinkertaistunut vuoden 1990 jälkeen. Nykyisin palkkatyötä tehdään Suomessa kolmannella sektorilla noin 77000 henkilötyövuotta. Se on noin viisi prosenttia koko kansantalouden henkilötyövuosien määrästä.

Järjestöjen tutkimista työnantajanäkökulmasta vaikeuttaa se, että työnantajana toimivista järjestöorganisaatioista ei ole yhtenäistä rekisteritietoa. Ainoastaan sosiaalipalveluiden tuottajista on kattavaa tietoa: niiden on tehtävä ilmoitus toiminnastaan. Esimerkiksi kulttuuri-, nuoriso- ja liikuntapalveluista vastaavaa tietoa ei ole saatavilla. (Pihlaja 2010,36)

Järjestöt ovat muihin organisaatioihin verrattuna erityislaatuisia työympäristöjä, sillä niitä johdetaan ja niissä työskennellään yhteistyössä vapaaehtoisten kanssa. Noin 12 prosenttia kolmannen sektorin palkatuista työntekijöistä on päätynyt tehtäväänsä vapaaehtoisuuden kautta (Ruuskanen ym. 2013). Rekrytointi vapaaehtoisten joukosta heijastaa muista työelämän sektoreista poikkeavia osaamistarpeita: on esimerkiksi osattava johtaa aatteellisuuteen perustuvaa työtä ja vapaaehtoisia (Bish \& Becker, 2016).

Palkkatyöntekijöiden ja vapaaehtoisten yhteistyö merkitsee usein joustamista työajoista. Työn ja perheen välisten ristiriitojen lisäksi kiire, epävarmuus ja toimintaedellytysten puute aiheutta- 
vat konflikteja järjestötyössä (Selander ym. 2012). Työn vaatimuksista sekä resurssien vähäisyydestä ja ennakoimattomuudesta johtuvista ristiriidoista huolimatta kolmannen sektorin työntekijät kokevat keskimääräistä enemmän työn merkityksellisyyttä ja imua (Selander ym. 2015).

\section{KOULUTUS AUTTAA SITOUTUMAAN JÄRJESTÖÖN}

Järjestö tarvitsee menestyäkseen kahdenlaista osaamista. Järjestön erityisalan, esimerkiksi terveyden tai ympäristön asiantuntemus, on perusta sen toiminnalle ja myös aihe, johon liittyvää osaamista hankitaan erikoistuneessa täydennyskoulutuksessa. Usein siihen liittyvä osaaminen varmistetaan jo rekrytointivaiheessa.

Toisaalta järjestöllä on oltava kyky mobilisoida ihmisiä, joten esimerkiksi viestinnän, kampanjoinnin ja vapaaehtoisten ohjaamisen taidot ovat tärkeitä (Fields 2005). Näihin liittyvää osaamista kehitetään herkimmin järjestöjen välisessä yhteistyössä.

Kaunismaan ja Lindin (2008) mukaan järjestötyössä yhdistyvätkin tyypillisesti eritysammattiosaaminen ja generalistinen järjestöosaaminen, kuten tiedotus ja projektinhallinta. Varsinkin pienissä järjestöissä työntekijöiden vastuualueet voivat toisinaan olla niin laajoja, etteivät he pysty määrittelemään itselleen selkeää ammattia (Ruuskanen ym. 2013).

Järjestöä palkkatyöntekijöiden ja vapaaehtoisten työyhteisönä muovaavat toiminnan kollektiivisuus ja yhteisöllisyys. Yhtäältä tämä tapahtuu sääntöjen kaltaisilla erottautumisen välineillä ja toisaalta yhteistä identiteettiä vahvistavilla kertomuksilla (esim. MacMillan \& McLaren 2012; Siisiäinen 2002). Tästä johtuu, että järjestöjen tarjoamat koulutus- ja oppimismahdollisuudet sisältävät usein kirjoittamattoman vastavuoroisuuden oletuksen: yksilö, joka kehittää omaa osaamistaan järjestössä, tuo sen yhteiseen käyttöön. Tämä näkyy myös siinä, että henkilöstökoulutukseen osallistuvat järjestötyöntekijät sitoutuvat muita paremmin edistämään järjestön toiminta-ajatusta. (Akingbola 2006; Fields 2005).
Työorganisaatioiden oppimisen ja kehittämisen teorioita on sovellettu järjestöihin toistaiseksi vähän osittain siksi, että sen työnantajarooli on korostunut vasta viime vuosikymmeninä (Bloch \& Borges 2002). Millesen ym. (2010) ovat soveltaneet seuraavia neljää organisaatioteoriaa analysoidessaan yhdysvaltalaisen järjestökentän henkilöstökehittämisen tarpeita:

1. strategisen johtamisen teoriaa, jonka mukaan osaamisen ja kyvykkyyden kehittämisen tarve on sisäsyntyistä ja tähtää toiminta-ajatuksen toteuttamiseen;

2. resurssiriippuvuusteoriaa, jonka mukaan järjestö pyrkii omista tarpeistaan käsin varmistamaan resursseja toiminnalleen, mistä seuraa erityisesti johtamistaidon tarpeita;

3. agenttiteoriaa, jonka mukaan osaamistarpeet määrittyvät ulkoisen päämiehen (rahoittaja) tarpeesta minimoida esimerkiksi hankerahoituksen riskejä vaatimalla, että agentti (järjestö) kouluttaa henkilöstöään;

4. institutionaalista teoriaa, jossa ulkoiset vaatimukset ajavat järjestöjä kehittämään osaamista legitimiteettinsä tueksi.

Tutkimuksessa haastatellut järjestöjohtajat korostivat mieluiten strategista johtamista, jossa organisaatio määrittelee itsenäisesti osaamisen kehittämistarpeet. Rahoittajien toiveet näkyvät taustalla, mutta usein osaava henkilöstö on rekrytoitu jo ennen rahoituksen hakemista. Tällöin taustalla vaikuttanee useammin järjestölähtöinen resurssiriippuvuus kuin agenttiteoriasta nouseva rahoittajan märitttelemä tarve.

Akingbola (2012) on kehittämässään järjestöjen strategisen henkilöstöjohtamisen mallissa hyödyntänyt resurssiriippuvuusteoriaa, koska järjestöt eivät käytännössä itsenäisyydestään huolimatta yleensä pysty toteuttamaan toiminta-ajatustaan ilman ulkoista rahoitusta, kuten toimintaavustuksia.

Kun organisaatioteorioita on sovellettu järjestötyöhön, on havaittu, että järjestöjen toimintaorientoituneisuus estää niitä pohtimasta oppimista ja kyvykkyyttä reflektiivisesti ja strategisesti. Niiden 
J ̈̈RJESTÖISS Ä

\section{TYÖSKENTELEVIST Ä}

LÄHES JOKA NELJÄS

ON M $̈ \ddot{A} R \ddot{A} A I K A I S E S S A$

TYÖSUHTEESSA.

tarjoama koulutuskin on toimintaan suuntautunutta. Reflektoinnin mahdollistaisivat muun muassa johtajuus ja se, että asianmukaiset rahalliset ja inhimilliset voimavarat varmistetaan.

Lisäksi haasteena on aatteellisuuden ja käytäntöjen yhteensopimattomuus. Strategioissa voidaan mainita halukkuus tehdä yhteistyötä mutta käytännössä siihen ollaan kyvyttömiä. (Esim. Smith 2014; Fields 2005; Bloch \& Borges 2002.) Tämä näkyy myös Opintokeskus Siviksen (Fields 2015) strategia-analyysissa, joka keskittyy sen jäsenjärjestöjen osaamiseen: verkostomainen jaettu asiantuntijuus nähdään tällä hetkellä järjestöissä ihanteena, mutta niiden strategioissa ei mainita keinoja edistää henkilöstön kykyä toimia verkostoissa ja hyödyntää esimerkiksi vertaisoppimista.

\section{MÄÄRÄAIKAISUUS LEIMAA JÄRJESTÖTYÖTÄ}

Järjestöissä työskentelevistä lähes joka neljäs on määräaikaisessa työsuhteessa. Määräaikaisuus on siis on huomattavasti yleisempää kuin yksityisellä tai suurimmalla osalla julkista sektoria. Työnantajilla on useita syitä märäaikaisuuksien käytölle. Perhevapaiden lisäksi niistä merkittävin on työllisyyden kasvu toimialalla (Sutela 2013).

Määräaikaiset työsuhteet painottuvat naisvaltaisille toimialoille (esim. Lehto \& Sutela 2008; Pärnänen \& Sutela 2011), ja ne ovat naisille tyypillisempiä myös kolmannella sektorilla. Sama tilanne on esimerkiksi Isossa-Britanniassa, jossa järjestösektorilla työskentelevät miehet löytävät vakituisen työpaikan naisia todennäköisemmin (Chartered Institute of Personnel and Recruitment 2014; Booth ym. 2002).
Määräaikaiseen työsuhteeseen hakeutumisen syistä merkittävimpiä ovat toive pysyvästä työpaikasta ja halu kartuttaa työkokemusta (Moorman \& Harland 2002). Joissain työpaikoissa määräaikaiset työntekijät eivät kuitenkaan saa samoja oikeuksia tai mahdollisuuksia kuin vakituisessa työsuhteessa olevat. Määräaikainen työsopimus saattaa esimerkiksi estää osallistumisen työnantajan tarjoamaan koulutukseen (Booth ym. 2002). Samalla määräaikaiset työntekijät kokevat, että heidän on pidettävä muita enemmän ammattitaitoaan yllä, koska työpaikat vaihtuvat (Miettinen 2007).

\section{TUTKIMUKSEN TOTEUTUS JA AINEISTO}

Artikkeli perustuu syksyllä 2014 sähköisellä kyselyllä kerättyyn aineistoon. Kyselyyn vastasi 844 eri alojen järjestöjen palkattua toimihenkilöä. Pääosa vastaajista (95 \%) työskenteli valtakunnallisen järjestön keskusjärjestössä tai piiritasolla. Vastausprosentti (24 \%) jäi kyselyssä heikoksi, mikä voi johtua haluttomuudesta vastata sähköiseen kyselyyn tai kyselyn joutumisesta vastaajan roskapostilaatikkoon. Tutkimusaineisto analysoitiin SPSS-tilasto-ohjelman avulla.

Kysely keräsi tietoa järjestötyöntekijöiden osaamisesta ja sen kehittämisestä. Koska määräaikaiset työsuhteet ovat sektorille tyypillisiä ja niiden osuus on kasvanut, tarkastelukohteiksi valittiin vakituisessa ja määräaikaisessa työsuhteessa olevat henkilöt. Lisäksi selvitettiin organisaatioon liittyvien tekijöiden, tässä koon ja toimialan, yhteyttä työntekijöiden osaamisen kehittämisen käytäntöihin.

Kysymyksessä osaamisen kehittämisestä vastaajaa pyydettiin merkitsemään kaikki ne osaamisen ylläpitämisen muodot, joita hän oli käyttänyt, sekä niistä kolme itselleen tärkeintä. Vaihtoehtoja oli kahdeksan. Lisäksi vastaajaa pyydettiin arvioimaan neljän väittämän avulla, miten osaamista kehitetään työpaikalla. Väittämät oli esitetty viisiportaisella asteikolla ( 1 = ei toteudu lainkaan, $5=$ toteutuu erittäin hyvin). Osaamisen kehittämisen haasteita kysyttiin avokysymyksellä. Avovastausaineisto luokiteltiin kvantitatiivista tarkastelua varten.

Akgündüz \& van Huizen (2015) ovat havainneet, että tyytyväisyys työhön ja muut työntekijän 
ja työn yhteensopivuutta kuvaavat tekijät ennustavat myös määräaikaisten työntekijöiden osallistumista henkilöstökoulutukseen. Vastaajia pyydettiinkin arvioimaan työn innostavuutta koskevaa väittämää neliportaisella asteikolla ( 1 = en lainkaan tyytyväinen, 4 = erittäin tyytyväinen).

\section{Tutkittavat}

Kyselyyn vastanneista hieman yli 70 prosenttia oli naisia. Järjestösektori onkin naisvaltainen: 85 prosenttia sen työvoimasta on naisia. Työnantajan näkökulmasta organisaatiot ovat pääosin pieniä tai keskisuuria. Kyselyyn vastanneista noin kolmannes toimi alle kymmenen hengen työyhteisössä. Vastaava rakenne löytyy esimerkiksi Isosta-Britanniasta, jossa pieniä järjestötyönantajia on noin kolmannes (Hopkins 2010).

Myös henkilöstön korkea koulutustaso on tyypillinen järjestösektorille sekä Suomessa että Isossa-Britanniassa (Hopkins 2010). Verrattain isolla osalla, 70 prosentilla, vastaajista $(\mathrm{N}=591)$ oli ammattikorkeatai korkeakoulutasoinen tutkinto, ja lisäksi 40 prosenttia oli suorittanut yliopistollisen jatkotutkinnon.

Aineiston tyypillisin henkilöstöryhmä olivat työntekijät. Työntekijöinä toimivien henkilöiden osuus oli suuri suhteutettuna korkeakoulutettujen määrään ja saattaa kertoa siitä, että osa työntekijöiksi itsensä määritelleistä vastaajista on todellisuudessa asiantuntijatason työtehtävissä.

Aineiston perusteella järjestösektorilta ei vaihdeta helposti toisille sektoreille. Vastaajat olivat keskimäärin kokeneita. Yli puolella vastaajista oli yli kymmenen vuoden työkokemus alalta.

Kaikista vastaajista 21 prosenttia oli määräaikaisessa työsuhteessa. Määräaikaisuuksia esiintyi kaikissa työtehtävissä. Projektirahoitusten vaikutus nousi esiin, sillä määräaikaisista työntekijöistä noin 60 prosentin työtehtäviin kuului projekti- tai hanketyötä, kun vakituisista sitä teki vain noin joka neljäs (23\%).

On kiinnostavaa, että kyselyyn vastanneista esimiehistä noin joka kymmenes työskenteli määräaikaisessa työsuhteessa. Määräaikaisuudet näyttävät muiden sektoreiden tavoin painottuvan työuran alkupuolelle, sillä tyypillisimmin määräaikaisuuksia tekivät 25-34-vuotiaat.

Määräaikaisuudet kasautuvat korkeakoulutetuille (taulukko 1). Ylemmän korkeakoulututkinnon suorittaneista vastaajista joka kolmas työskenteli määräaikaisena ja ammattikorkeakoulututkinnon suorittaneista joka neljäs.

\begin{tabular}{|l|c|c|}
\hline & Vakituiset $\%(\mathbf{N}=655)$ & Määräaikaiset \% (N = 178) \\
\hline Naisia & 78,4 & 85,7 \\
\hline Miehiä & 21,6 & 14,3 \\
\hline Yhteensä & 100,0 & 100,0 \\
\hline Esimiesasema & 26,3 & 14,0 \\
\hline Asiantuntija & 34,2 & 38,2 \\
\hline Työntekijä & 39,5 & 47,8 \\
\hline Yhteensä & 100,0 & 100,0 \\
\hline Korkeakoulutus & 71,3 & 91,9 \\
\hline Ei korkeakoulutusta & 28,7 & 8,1 \\
\hline Yhteensä & 100,0 & 100,0 \\
\hline Työskentelee isossa järjestössä & 35,2 & 29,5 \\
\hline Työskentelee pienessä järjestössä & 64,8 & 70,5 \\
\hline Yhteensä & 100,0 & 100,0 \\
\hline
\end{tabular}

Taulukko 1. Vastaajien taustatiedot työsuhteen tyypin mukaan (\%). 


\begin{tabular}{|l|c|c|c|c|}
\hline & Vakituiset ka. & sd. & Määräaikaiset ka. & sd. \\
\hline Osaamiseni vastaa työn vaatimuksia & 4,1 & 0,63 & 4,0 & 0,72 \\
\hline $\begin{array}{l}\text { Pidän huolta oman osaamisen } \\
\text { ylläpitämisestä }\end{array}$ & 3,9 & 0,85 & 3,9 & 0,79 \\
\hline $\begin{array}{l}\text { Työpaikkani tarjoaa mahdollisuuksia osaami- } \\
\text { sen kehittämiseksi }\end{array}$ & 3,6 & 1,04 & 3,5 & 0,96 \\
\hline $\begin{array}{l}\text { Olen keskustellut esimieheni kanssa } \\
\text { osaamisen ylläpitämisestä*** }\end{array}$ & 3,6 & 1,12 & 3,2 & 1,17 \\
\hline
\end{tabular}

${ }^{*}=$ p. $<0,05,{ }^{* *}=$ p. $<0,01, * * *=p .<0,001$

Taulukko 2. Vakituisten ja määräaikaisten työntekijöiden osaamisen hallinta, keskiarvot ja -hajonnat (1 = ei toteudu lainkaan, 5 = toteutuu erittäin hyvin).

Sähköiset tietolähteet

Työkaverit*

Kirjallisuus

Lehdet

Muu ammatillinen koulutus*

Työnantajan järjestämä koulutus

Harrastukset

Sosiaalinen media***

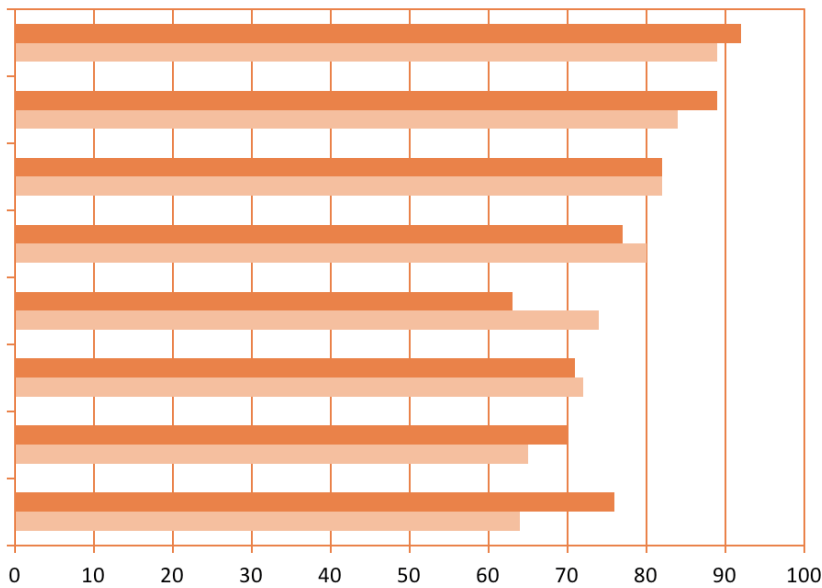

Määräaikainen

Vakituinen

${ }^{*}=$ p. $<0,05,{ }^{* *}=$ p. $<0,01,{ }^{* *}=$ p. $<0,001$

Kuvio 1. Osaamisen ylläpitämisen tavat tai lähteet työsuhteen laadun mukaan (\%).

\begin{tabular}{|l|c|c|}
\hline & Työnantajan järjestämä \% & Työpaikan ulkopuolinen \% \\
\hline Sosiaali- ja terveysala $(\mathrm{N}=316)$ & 81,3 & 79,7 \\
\hline Liikunta, harrastus ja kulttuuri $(\mathrm{N}=190)$ & 57,9 & 64,7 \\
\hline Ammatillinen ja poliittinen $(\mathrm{N}=42)$ & 59,4 & 52,4 \\
\hline Palvelu, pelastus ja neuvonta $(\mathrm{N}=80)$ & 91,3 & 76,3 \\
\hline Kasvatus ja nuoriso $(\mathrm{N}=78)$ & 69,2 & 71,8 \\
\hline Muut & 57,4 & 66,2 \\
\hline
\end{tabular}

Taulukko 3. Koulutuksiin osallistuneiden prosenttiosuus järjestöryhmittäin (\%). 
TYÖSUHTEEN LAATU VAIKUTTAA OPPIMISTAPOIHIN

Osaamiseen ja sen kehittämisen mahdollisuuksiin liittyviä käsityksiä kerättiin neljän väittämän avulla. Vakituisten ja määräaikaisten työntekijöiden vastauksia verrattiin t-testillä (taulukko 2).

Väittämien "Osaamiseni vastaa työn vaatimuksia", "Pidän huolta oman osaamisen ylläpitämisestä" ja "Työpaikkani tarjoaa mahdollisuuksia osaamisen kehittämiseksi" keskiarvoissa ei ollut tilastollista eroa eri työsuhdetyyppien välillä. Sen sijaan väittämä "Olen keskustellut esimieheni kanssa osaamiseni ylläpitämisestä" tuotti eron: vakituisessa työsuhteessa olevat arvioivat väittämän toteutuvan merkitsevästi paremmin kuin määräaikaisessa työsuhteessa olevat.

Vastaajia pyydettiin valitsemaan kaikki ne osaamisen kehittämisen tavat tai lähteet, joita he olivat käyttäneet (kuvio 1). Työnantajan työpaikalla tai muuten järjestämään koulutukseen sekä muuhun ammatilliseen koulutukseen ilmoitti osallistuneensa noin 70 prosenttia vastaajista. Osuus oli hieman korkeampi kuin viimeisimmässä aikuiskoulutustutkimuksessa (Niemi ym. 2014) mutta vastaa yleistä korkeakoulutettujen keskiarvoa.

Pienissä, alle kymmenen henkilön työpaikoissa osallistutaan koulutuksiin suurempia työpaikkoja harvemmin. Työnantajan järjestämään koulutukseen osallistuu 59 prosenttia ja muuhun ammatilliseen koulutukseen 66 prosenttia työntekijöistä.

Eri tapoja ylläpitää osaamista verrattiin työsuhteen laadun mukaan. Määräaikaiset työntekijät mainitsivat vakituisia useammin oppimismuotona työkaverit ja sosiaalisen median, vakituiset puolestaan määräaikaisia useammin työpaikan ulkopuolisen ammatillisen koulutuksen.

Vastauksia tarkasteltiin myös toimialan mukaan (taulukko 3), jotta selviäisi, vaikuttavatko eri tahojen pääasialliset rahoituslähteet tai järjestön toimintamuoto koulutukseen osallistumiseen. Alkuperäisen aineiston luokkia yhdisteltiin ryhmäkohtaisen vastaajamäärän kasvattamiseksi, jolloin saatiin aikaan viisi ryhmää: 1) sosiaali- ja terveysala, 2) liikunta, harrastus ja kulttuuri, 3) ammatillinen ja poliittinen, 4) palvelu, pelastus ja neuvonta sekä 5) muut (muun muassa ympäristö, kehitys, uskonto).

Aktiivisimmin koulutuksiin osallistuivat sosiaali- ja terveysalan järjestöissä sekä palvelu- ja neuvonta-alan järjestöissä työskentelevät. Vähiten henkilöstökoulutukseen osallistutaan liikunta-, harrastus- ja kulttuurijärjestöissä.

Näyttää siltä, että runsaasti palveluja tuottavat järjestöt, kuten sosiaali- ja terveysalan järjestöt, joilla on suhteellisen paljon palkattua ammattihenkilöstöä, kouluttavat henkilökuntaansa runsaasti. Toisaalta viranomaisyhteistyö luo esimerkiksi pelastusalan järjestöille tarpeita kehittää osaamistaan (esim. Fields 2005).

Vastaajia pyydettiin lopuksi mainitsemaan kolme itselle tärkeintä/pääasiallisinta oppimismuotoa. 60 prosenttia vakituisista työntekijöistä piti tärkeimpänä oppimisen muotonaan työpaikan ulkopuolista ammatillista koulutusta, kun määräaikaisista sitä piti tärkeimpänä 50 prosenttia.

Eniten mainintoja määräaikaisilta vastaajilta saivat työkaverit. Sen mainitsi tärkeimmäksi oppimismuodokseen 51 prosenttia määräaikaisessa mutta vain 35 prosenttia vakituisessa työsuhteessa työskentelevistä vastaajista. Kummankin oppimismuodon kohdalla erot vastaajaryhmien välillä ovat tilastollisesti merkitseviä (p. <0,05).

On kiinnostavaa, että vaikka tilastollista eroa ei muiden oppimismuotojen kohdalla syntynyt, vakituisessa työsuhteessa työskentelevät vastaajat pitivät koulutuksia tärkeinä osaamisen kehittämiselle, kun taas määräaikaiset työntekijät mainitsivat pääasiallisina oppimistapoinaan informaaleja eli arkioppimisen muotoja, kuten työkaverit ja sosiaalinen media. Työnantajan tarjoaman koulutuksen merkitys ei riippunut eri työsuhdetyypeistä mutta järjestön koosta kyllä: pienissä järjestöissä työskentelevistä 36 prosenttia piti työnantajan järjestämää koulutusta tärkeänä, kun suuremmissa järjestöissä osuus oli 46 prosenttia (p. <0,01).

Tärkeimpiä ja toisistaan melkoisesti poikkeavia oppimisen lähteitä, työpaikan ulkopuolista ammatillista koulutusta ja työkavereita, tarkasteltiin kahden erillisen logistisen regressioanalyysin avulla. Tavoitteena oli selvittää, onko työsuhteen laadun 
lisäksi muita yksilöllisiä tai organisaatioon liittyviä tekijöitä, joilla voi olla vaikutusta siihen, millaista osaamisen kehittämisen muotoa työntekijä pitää tärkeänä. Mallien selitysvoima jäi kuitenkin melko heikoksi, joten tuloksia voidaan pitää lähinnä suuntaa-antavina.

Molempiin analyyseihin otettiin taustamuuttujiksi työsuhteen laatu, sukupuoli, organisaation koko, ammattiasema sekä alan työkokemus. ${ }^{i}$ Analyysin tulokset osoittavat, että työsuhteen laatu vaikuttaa siihen, miten tärkeiksi eri oppimistavat koetaan.

Mallissamme työpaikan ulkopuolisen ammatillisen koulutuksen tärkeyttä selittää työsuhteen laadun lisäksi sukupuoli $(\beta=0,81, p<0,001)$. (Taulukko 4.) Naisvastaajista noin 74 prosenttia $(\mathrm{N}=493)$ mainitsi työpaikan ulkopuolisen koulutuksen tärkeäksi, kun taas miehistä näin vastasi 59 prosenttia $(\mathrm{N}=59)$. Tämä selittynee naisten yleisellä aktiivisuudella ottaa osaa työelämään liittyvään tai henkilöstökoulutukseen (Suomen virallinen tilasto 2016).

Toisessa regressiomallissa työkavereiden tärkeyttä selittävät työsuhteen laatu $(\beta=-0,44 ; \mathrm{p}<0,05)$ ja työkokemus $(\beta=0,61 ; \mathrm{p}<0,01)$ : työsuhteen määräaikaisuus ja vähäinen työkokemus lisäävät mallissa työkavereiden merkitystä oppimisen lähteenä.

Lisäsimme malleihin toisessa vaiheessa muuttujan "Työni on innostavaa". Innostus ei näytä selittävän työpaikan ulkopuolisen koulutuksen tärkeyttä. Sen sijaan työkavereiden tärkeyden osalta tulos on melkein merkitsevä (p. < 0,05): ne vastaajat, jotka ovat innostuneita työssään, pitivät työkavereita tärkeinä oppimiselleen. Muiden muuttujien osalta merkitsevyydet pysyvät ennallaan.

\section{ESTEITÄ OSAAMISEN KEHITTÄMISEN TIELLÄ}

Osaamisen kehittämisen vaikeuksia kerättiin avokysymyksellä "Koetko osaamisen kehittämisen haasteelliseksi?" Vastaajaa pyydettiin myös mainitsemaan, mistä haasteesta on kyse. Kyselyaineistosta oli koodattavissa yhteensä 479 haastetyyppiä tai -tilannetta, joista vakituiset työntekijät mainitsivat 373 ja märäaikaiset työntekijät 106.

Tyypillisin oman osaamisen kehittämisen haaste järjestötyöpaikoilla on kiire tai ajanpuute. Sen mainit- si noin kolmannes sekä määräaikaisista että vakituisista työntekijöistä. Sen sijaan taloudellisten resurssien puutteen mainitsivat huomattavasti useammin vakituiset kuin määräaikaiset, mikä saattaa johtua siitä, etteivät järjestöjen tietyt toimintatavat koske esimerkiksi projektityöntekijöitä. Määräaikaisilla työntekijöillä toisiksi tyypillisin haaste oli koulutusta tukevien käytäntöjen puute työpaikalla. (Taulukko 5.)

Monet vastaajat kuvasivat arkea niin kiireiseksi, ettei aikaa osaamisen kehittämiselle jää eikä sitä ollut aikataulutettu. Kiireen syyt olivat samoja määräaikaisilla ja vakituisilla työntekijöillä: esimerkiksi työmäärä ja työpaikan pieni koko, jonka takia työstä on vaikea irrottautua. Määräaikaisilla työntekijöillä korostuivat projekteihin liittyvät aikapaineet sekä se, ettei valmistautumista pidempää uraa varten nähty mielekkäänä työn epävarmuudesta johtuen.

"Määräaikaisissa työsuhteissa ei aina ole mahdollisuuksia (tai harvoin) työnantajan järjestämään koulutukseen, jolloin koulutuksen järjestäminen jää omalle vastuulle.” (Nainen, määräaikaisessa asiantuntija-asemassa)

"Olen tehnyt useita vuosia töitä projekteissa, joten osaamisen kehittäminen on vaikeaa kun ei tiedä missä seuraavaksi työskentelee. Projektityöhön ja arviointiin liittyviä koulutuksia olen käynyt, mutta esimerkiksi kohtaamiseen tai henkilökohtaiseen tukemiseen liittyviä koulutuksia en ole käynyt, koska periaatteessa nämä työtehtävät eivät työnkuvaani kuulu, mutta silti niitä satunnaisesti teen.” (Mies, määräaikaisessa esimiestehtävässä)

Työntekijät eivät usein tunnista arkityössä tapahtuvaa oppimista, vaan oppimisen lähteenä pidetään koulutusta. Osa vastaajista koki, että työn kiireisyyden vuoksi osaamista olisi kehitettävä vapaa-ajalla. Vastauksista nähdään, että järjestötyöhön yleisesti liitetty autonomia sekä työn ja vapaa-ajan välisen eron hämärtyminen (Selander ym. 2012) ulotetaan myös oman osaamisen kehittämiseen.

"Osaamisen kehittäminen jää usein omalle vapaa-ajalle, jos projekteissa tai työssä on kiireistä." (Nainen, määräaikaisessa työntekijäasemassa) 


\begin{tabular}{|l|c|c|c|c|c|c|}
\hline & Muu ammatillinen koulutus & \multicolumn{3}{|c|}{ Infomaali oppiminen } \\
\hline & $B$ & S.E. & p-arvo & $B$ & Sd. & p-arvo \\
\hline Sukupuoli (1 = nainen, 0 = mies) & 0,81 & 0,27 & $0,00 * * *$ & $-0,13$ & 0,19 & 0,48 \\
\hline $\begin{array}{l}\text { Ammattiasema (1 = esimies, 0 = ei esimies- } \\
\text { asemaa) }\end{array}$ & 0,08 & 0,18 & 0,67 & $-0,04$ & 0,18 & 0,81 \\
\hline $\begin{array}{l}\text { Työsuhteen laatu (1 = vakituinen, } \\
\text { = määräaikainen) }\end{array}$ & 0,39 & 0,20 & $0,04^{*}$ & $-0,44$ & 0,19 & $0,03^{*}$ \\
\hline $\begin{array}{l}\text { Työkokemus alalla, vuotta (1 = alle 3, } \\
0=\text { vähintään 3) }\end{array}$ & $-0,23$ & 0,22 & 0,28 & 0,61 & 0,21 & $0,01 * * *$ \\
\hline $\begin{array}{l}\text { Työpaikan koko (1 = alle 10, 0 = vähintään } \\
10)\end{array}$ & $-0,08$ & 0,16 & 0,60 & $-0,23$ & 0,16 & 0,15 \\
\hline
\end{tabular}

${ }^{*}=$ p. $<0,05,{ }^{* *}=$ p. $<0,01, * * *=p .<0,001$, Cox \& Snell $R^{2}=0,03$

Taulukko 4. Taustamuuttujien yhteys erilaisten oppimistapojen tyypillisyyteen/tärkeyteen, logistinen regressioanalyysi.

\begin{tabular}{|l|c|c|}
\hline & Vakituiset $\%(\mathrm{~N}=373)$ & Määräaikaiset \% $(\mathrm{N}=106)$ \\
\hline Kiire tai ajanpuute & 37,0 & 33,0 \\
\hline Taloudelliset resurssit & 13,7 & 3,8 \\
\hline Ei tarjolla sopivaa koulutusta & 9,1 & 6,6 \\
\hline Muu & 8,8 & 4,7 \\
\hline Liian laaja tehtävänkuva & 8,0 & 8,5 \\
\hline Omaehtoisen koulutuksen vaade & 6,4 & 2,8 \\
\hline Nopea muutos toimintaympäristössä & 5,4 & 9,4 \\
\hline Ei koulutusta tukevia käytäntöjä & 5,4 & 0,9 \\
\hline Ei kehittämishalua & 1,1 & 4,7 \\
\hline Määräaikaisuus & 0,0 & 4,7 \\
\hline
\end{tabular}

Taulukko 5. Osaamisen kehittämisen haasteet järjestötyöpaikoilla (\%).

"Sille ei tunnu riittävän tarpeeksi aikaa kiireisen työpäivän aikana ja monesti sen jälkeen on jo liian väsynyt.” (Nainen, määräaikaisessa asiantuntija-asemassa)

”Tällä hetkellä työmäärä on niin paljon, että, harrastuksien kera, ei jää paljon aikaa ja voimia osaamisen kehittämiseen." (Mies, määräaikaisessa työntekijäasemassa)

Osaamista saatettiin vapaa-ajalla kehittää opiskelemalla työssä tarvittavia erityistaitoja, kuten kieltä, tai kehittämällä laajemmin omaa osaamista esimerkiksi tulevaa työuraa ajatellen. Vastaukset paljastavat, että osaamisen kehittäminen nähtiin itsenäisenä, työstä irrallisena kokonaisuutena, vaikka esimerkiksi projektityö sisältää yleensä uusia kokonaisuuksia ja työtapoja.
Koulutusta tukevien käytäntöjen puutteella tarkoitettiin useimmiten tilannetta, jossa osaamisen kehittämisestä ei ollut lainkaan keskusteltu tai vastaaja koki, ettei työnantaja ei arvostanut tai tukenut sitä. Se jäi vastaajan omalle vastuulle ja perustui omaan aktiivisuuteen. Vastauksissa toivottiin, että työnantaja ehdottaisi selkeämmin osaamisen kehittämisen tapoja ja asettaisi tavoitteita.

\section{KÄYTÄNNÖT JA IDEAALIT EIVÄT KOHTAA}

Tässä artikkelissa on vertailtu vakituisessa ja määräaikaisessa työsuhteessa järjestöissä työskentelevien palkansaajien näkemyksiä osaamisen kehittämisen tavoista ja tarkasteltu rakenteellisten tekijöiden yhteyttä niihin. 
J ̈̈RJESTÖJEN HENKILÖSTÖ

ON KESKIMÄ̈̈RIN

KORKEASTI KOULUTETTUA

JA NAISVALTAISTA.

Järjestöjen henkilöstö on keskimäärin korkeasti koulutettua ja naisvaltaista ja tekee alalla pitkiä työuria. Naisvaltaisuus ja korkea koulutustaso näkyvät isommilla työnantajilla aktiivisena osallistumisena koulutuksiin. Pienissä järjestöissä työskentelevät osallistuvat koulutuksiin muita harvemmin ja pitävät työnantajan koulutusta vähemmän tärkeänä tapana kehittää osaamistaan.

Työelämän muutokset, kuten kilpailun kiristyminen, ovat tuoneet paineita monelle järjestötyöpaikalle. Osa työntekijöistä kokee työtahdin hyvin kiireiseksi, ja on syytä olettaa, että työn arvopohjainen ulottuvuus lisää työn vaatimuksia. Näyttäisi siltä, että erityisesti pienessä yksikössä kiire ja tehtävät kasautuvat, ja osaamisen kehittämiselle on vaikeaa löytää riittävästi aikaa.

Monet määräaikaisessa työsuhteessa olevat pitävät informaalin oppimisen muotoja, kuten työkavereita ja sosiaalista mediaa, itselleen tärkeämpinä osaamisen kehittämisen tapoina kuin vakituisessa työsuhteessa olevat. Vakituisessa työsuhteessa olevat pitävät sen sijaan määräaikaisia vastaajia useammin tärkeänä työpaikan ulkopuolista koulutusta. Syy saattaa löytyä työtehtävästä: projektiluontoiseen työhön voi olla vaikea löytää sopivaa koulutusta. Toisaalta tulosta voi selittää vakituisten työntekijöiden työhistoria. He pyrkivät laajentamaan osaamistaan oman työnsä ja työyhteisönsä ulkopuolelta.

Vaikka työnantajan järjestämään koulutukseen osallistumisessa ei ollut eroa, määräaikaiset työntekijät eivät keskustelleet osaamisen kehittämisestä esimiestensä kanssa mielestään läheskään yhtä usein kuin vakituisessa työssä olevat. Silti vakituisistakaan työntekijöistä kaikki eivät kokeneet keskusteluyhteyttä olevan.
Organisatorisen oppimisen teorioista johdettu havainto, että järjestöissä ei muun muassa toimintaorientoituneisuuden takia pohdita osaamista strategisesti ja että käytännöt ja ideaalitila eivät usein vastaa toisiaan, näkyy myös tässä aineistossa ja erityisesti määräaikaisten työntekijöiden kohdalla. Lähes kymmenesosa määräaikaisessa työsuhteessa olevista vastaajista koki osaamisen kehittämisen esteeksi sen, ettei siihen ole työpaikalla käytäntöjä.

Jatkotutkimuksessa työnantajan tarjoamaa koulutusta tulisi tarkastella tarjotun koulutuksen sisällön näkökulmasta sekä tutkia työpaikkojen osaamisen kehittämisen rakenteita. Tämä aineisto ei riitä vastaamaan siihen, onko työnantajien tarjoama koulutus kestoltaan ja laadultaan tasavertaista kaikille.

Järjestöissä erityisesti ylemmän johdon, kuten järjestöpäälliköiden, rooliin ja erityisosaamiseen kuuluu osaamisen kehittäminen (Bish \& Becker 2016). Säännöllinen keskustelu ja vuorovaikutus sekä hyödyn arvioinnin mittareiden tuominen järjestöorganisaatioihin on suositeltavaa, jotta asiantuntijuus ja motivaatio kehittää sitä edelleen turvataan.

Näiden tulosten valossa järjestötyönantajien tulisi kiinnittää aiempaa enemmän huomiota määräaikaisten työntekijöiden tukemiseen. Osaamista tulisi johtaa rinnakkain strategisten käytäntöjen kanssa, käytettävissä oleva henkilöstö huomioiden. Riittävä osaaminen ja työnhallinta tukevat tuottavuutta ja työhyvinvointia. Jos osaamisen johtamisesta ei koeta tai tunnisteta saatavan hyötyä, motivaatio kehittää osaamista on heikko (Hyrkäs 2009).

Määräaikaisten työntekijöiden johtamisessa on myös kysymys nopeasti muuttuvien toimintaedellytysten hallinnasta. Esimerkiksi hanketyöntekijät on usein rekrytoitu määräaikaiseen tehtävään jo rahoitusta vastaanotettaessa, eikä rahoituspäätökseen yleensä liity koulutusvaatimusta. Näin riski heidän osaamisensa hallinnasta ei liity suoraan rahoittajan määräyksiin, vaan taustalla ovat järjestön sisäiset kehittämistarpeet. Tilanne on samankaltainen kuin Millesenin ym. (2010) haastattelemien yhdysvaltalaisten järjestöjohtajien keskuudessa: taustalla vaikuttaa todennäköi- 
sesti resurssiriippuvaisuusteorian näkemyksiä vastaava todellisuus.

Tätä käsitystä tukee havainto siitä, että sosiaali- ja terveys- sekä neuvonta-, pelastus- ja palvelujärjestöjen ryhmään kuuluvia järjestöjä edustaneet vastaajat kokivat muita useammin koulutuksen tärkeäksi osaksi oman osaamisensa kehittämistä. Moni näiden alojen järjestöistä on tekemisissä ulkoisten rahoittajien kanssa joko avustusten tai ostopalvelusopimusten kautta, joten ammatillistumisen paineet ovat kovat. Suhde ulkoiseen rahoittajaan saattaa määritellä koulutustarpeita usein silloinkin, kun niitä ei agenttiteoriasta johdettujen ajatusten mukaisesti rahoittaja määrittele suoraan.

Erityisesti niissä organisaatioissa, joissa on paljon hanketoimintaa, on vaikea ylläpitää määräaikaisten työntekijöiden osaamista ja varmistaa, että osaaminen siirtyy työyhteisössä eteenpäin. Viimeisimmän työolotutkimuksen mukaan noin kolmannes kaikista työntekijöistä Euroopassa on osallistunut työnantajan järjestämään koulutukseen. Suomessa ja Ruotsissa joka viidennes on pyytänyt päästä koulutukseen, mutta toive ei ole toteutunut. (Kauppinen ym. 2013.)

Vaarana on, että järjestöstä toiseen hanketyössä siirtyvät ja monia määräaikaisuuksia tekevät työntekijät eivät useinkaan pääse koulutukseen. Hankerahoitus ei läheskään aina ulotu tähän eikä tätä huomioida muuten järjestön budjetissa.

Koulutukseen osallistumisen eroja henkilöstöryhmien välillä olisi syytä tutkia tarkemmin. Muun muassa tuoreimman aikuiskoulutustutkimuksen mukaan (Niemi ym. 2014) pidempi pohjakoulutus sekä parempi sosioekonominen ja työpaikan hierarkkinen asema edistävät koulutuksiin osallistumista. Määräaikaiselle työntekijälle koulutus oman talon ulkopuolella mahdollistaa verkostoitumisen, mikä voi edistää hänen työllistymistään tulevaisuudessa. Tämä tukee myös järjestöjen strategista tavoitetta toimia verkostomaisesti. Toistaiseksi se on toteutunut heikosti. Pienissä järjestöissä on syytä etsiä tapoja tukea osaamista silloinkin, kun resursseja on käytössä niukasti.

Oppimisen ei tarvitse aina tapahtua koulutuksessa, vaan suunnitelmallista kehittämistä voi tehdä esimerkiksi työparityöskentelynä. Osaamisen kehittämisestä tarkasteltaessa olisikin ylipäätään puhuttava laajemmin oppimisesta kuin koulutuksesta. Oppiminen on mahdollista eriasteisesti organisoituneissa tilanteissa. (Paloniemi 2004.) Sen tunnistamiseen liittyy kuitenkin hankaluuksia, ja esimerkiksi vakituista työtä haettaessa kouluttautuneet työntekijät saattavat olla muulla tavoin oppineita työntekijöitä vahvemmilla.

Toisaalta järjestöjen työntekijät muodostavat jonkin verran epämuodollisia ja myös muodollisempia käytäntöyhteisöjä (Lave \& Wenger 1991) samanlaista työtä toisessa organisaatiossa tekevien työntekijöiden kanssa verkostojen ja yhteishankkeiden kautta. Wengerille (2000) nämä kohtaamiset ovat potentiaalinen uuden oppimisen lähde. $\mathrm{Ne}$ siirtävät tietoa yhteisöjen välillä. Samalla voi löytyä kouluttautumistapoja niille, jotka kokevat sopivan koulutuksen puutteen merkittäväksi osaamisensa kehittämisen esteeksi.

Olisikin kiinnostavaa tarkastella jatkossa työyhteisöjen keskinäisen oppimisen sisältöjä ja mekanismeja järjestötyössä. Erityisesti aatteellisuuden hallinta on järjestöille ominaista, ja sitä voi olla vaikea opiskella työpaikan ulkopuolella (ks. esim. Bish \& Becker 2016). Henkilöstökoulutukseen osallistuminen myös lisää sitoutumista järjestön toimintaajatukseen ja arvoihin (Akingbola 2006). Tämä voi vaikuttaa tulevaisuudessa tapoihin kehittää osaamista järjestötyöpaikoilla suunnitelmallisesti.

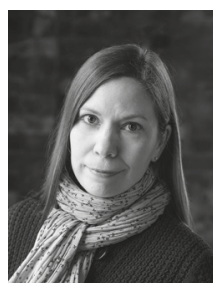

HEIDI RISTOLAINEN

VTM, asiantuntija

Opintokeskus Sivis

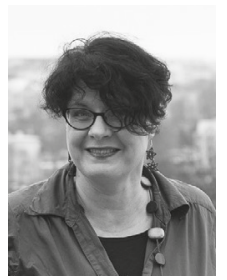

MARION FIELDS

VTT, asiantuntija Opintokeskus Sivis 
'Työsuhteen laadun ohelle muuttujat valittiin seuraavasti: Sukupuoli otettiin mukaan, koska vuoden 2012 Aikuiskoulutustutkimuksessa (Suomen virallinen tilasto 2016) naiset osallistuvat työhön liittyvään tai henkilöstökoulutukseen aktiivisemmin kuin miehet. Ero oli aiempiin vuosiin nähden kasvanut.

Saman tutkimuksen mukaan toimihenkilöt osallistuvat henkilöstökoulutuksiin työntekijöitä useammin, ja eniten henkilöstökoulutukseen osallistuvat isoissa yrityksissä työskentelevät. Järjestösektorilla työpaikan koko vaikuttaa henkilöstökoulutukseen osallistumiseen myös esimerkiksi Isossa-Britanniassa (Brewis \& Stevens 2010).
Työsuhteen kesto valittiin, koska on viitteitä siitä, että pitkä työura tai määräaikaisen työntekijän pitkä työsuhde samaan työnantajaan lisää henkilöstökoulutukseen osallistumisen todennäköisyyttä kolmannella sektorilla (Akgündüz \& van Huizen, 2015; Brewis jne. 2010).

Innostusta kysymällä testattiin Akgündüzin \& van Huizenin (2015) tulosta, jonka mukaan työntekijän ja työn yhteensopivuus ennustaa mahdollisuutta osallistua useammin koulutuksiin sekä todennäköisyyttä saada vakituinen työpaikka. He operationalisoivat yhteensopivuuden työtyytyväisyyden ja työsuhteen keston avulla.

\section{LÄHTEET}

Akgündüz, Y. \& van Huizen, T. (2015). Training in twotier labor markets: The role of job match quality. Social Science Research 52, 508-521.

Akingbola, K. (2012). A model of strategic nonprofit human resource management. Voluntas 24, 214-240.

Akingbola, K. (2006). Strategy and HRM in nonprofit organizations: evidence from Canada. The International Journal of Human Resource Management 17:10, 1707-1725.

Anheier, H. K., Carlson, L. \& Kendall, J. (2012). Third sector policy at the crossroads. Continuity and change in the world of nonprofit organizations. Teoksessa Anheier, H. K. \& Kendall, J. (toim.) Third Sector Policy at the Crossroads. An International Non-profit Analysis. Lontoo \& New York: Routledge.

Bish, A. \& Becker, K. (2016). Exploring expectations of nonprofit management capabilities. Nonprofit and Voluntary Sector Quarterly 45:3, 437-457.

Bloch, D. \& Borges, N. (2002). Organisational learning in NGOs: An example of an intervention based on the work of Chris Argyris. Development in Practice 12(3-4), 461-472.

Booth, A., Francesconi, M. \& Frank, J. (2002). Temporary jobs: stepping stones or dead ends? The Economic Journal 112, 198-213.

Carmel, E. \& Harlock, J. (2002). Instituting the 'third sector' as a governable terrain: partnership, procurement and performance in the UK. Policy \& Politics 36(2), 155-71. https://www. researchgate. net/profile/Jenny_Harlock/publication/233591493_ Instituting_the_'third_sector'_as_a_governable_ terrain_Partnership_procurement_and_performance_ in_the_UK/links/5592619008ae15962d8e60f1.pdf (8.2.2017)

Brewis, G., Hill, M. \& Stevens, D. (2010). Valuing Volunteer Management Skills. Lontoo: Institute for
Volunteering Research. http://www.ivr.org.uk/images/ stories/Institute-of-Volunteering-Research/MigratedResources/Documents/NNaluing_volunteer_ management_skills.pdf (3.8.2016)

Chartered Institute of Personnel and Development (2014). Labour Market Outlook. http://www.cipd. co.uk/binaries/labour-market-outlook_2014-spring. pdf (3.10.2016)

Fields, M. (2015). Koulutus järjestön voimavarana. Helsinki: Opintotoiminnan Keskusliitto ry. https:// www.ok-sivis.fi/media/materiaalit-osio/selvityksetja-tutkimukset/koulutus-jarjeston-voimvarana.pdf (5.2.2017).

Fields, M. (2005). To Educate, Empower or Economise? Lifelong Learning in Civil Society Organisations. Turku: Koulutussosiologian tutkimuskeskus, Turun yliopisto.

Heikkala, J. (2001). Järjestön strategia. Käsikirja elinvoimaisen tulevaisuuden luomiseen. Tampere: Tampere University Press.

Hopkins, L. (2010). Mapping the Third Sector: A Context for Social Leadership. Lontoo: The Work Foundation. http://docplayer.net/19354896-Mapping-thethird-sector-a-context-for-social-leadership.html (5.2.2017)

Hyrkäs, E. (2009). Osaamisen johtaminen Suomen kunnissa. Acta Universitatis Lappeenrantaensis 338. Lappeenranta: Lappeenrannan tekninen yliopisto.

Kauppinen, T., Mattila-Holappa, P., Perkiö-Mäkelä, M., Saalo, A., Toikkanen, J., Tuomivaara, S., Uuksulainen, S., Viluksela, M. \& Virtanen, S. (2013). Työ ja terveys Suomessa 2012. Seurantatietoa työoloista ja työhyvinvoinnista. Helsinki: Työterveyslaitos.

Kaunismaa, P. \& Lind, K. (2008). Generalisteja vai spesialisteja? Ammatillisen järjestötyön kvalifikaatioiden tarkastelua. Teoksessa 
Holopainen, A., Lind, K. \& Niemelä, J. (toim.) Ammattikorkeakoulut kansalaistoiminnassa. Oikeusministeriön julkaisuja 2008:7.

Ketola, T. (2015). Strategiatyöstä tulevaisuustyöhön. Toiminnallinen tapaustutkimus Suomen Luonnonsuojeluliitossa. Sosiaalitieteen julkaisuja 2015:11. Helsinki: Unigrafia.

Lave, J. \& Wenger, E. (1991). Situated Learning: Legitimate Peripheral Participation. Cambridge: Cambridge University Press.

Lehto, A.-M. \& Sutela, H. (2008). Työolojen kolme vuosikymmentä. Työolotutkimusten tuloksia 19772008. Helsinki: Multiprint.

Merrill, M. V. \& Safrit, R. D. (2003) International megatrends in volunteerism. Voluntary Action 5(2), 63-69. http://www.ivr.org.uk/images/stories/Instituteof-Volunteering-Research/VA-Documents/VA5_2/ article6_merrilletal.pdf (8.2.2017).

Miettinen, A. (2007). Pätkätyön tulevaisuus? Asiantuntijanäkemyksiä määräaikaisen työn kehittämistarpeista ja tulevasta kehityksestä Suomessa. Katsauksia E 27. Helsinki: Väestöliitto.

Millesen, J. L.; Carman, J. G. \& Bies, A. L. (2010). Why engage? Understanding the incentive to build nonprofit capacity. Nonprofit Management 6 Leadership 21(1), 5-20.

Moorman, R. \& Harland, L. (2002). Temporary employees as good citizens: factors influencing their ocb performance. Journal of Business and Psychology 17(2), 171-187.

Niemi, H., Ruuskanen, T. \& Seppänen, T. (2014). Osallistuminen aikuiskoulutukseen vuonna 2012. Helsinki: Tilastokeskus.

Opetus- ja kulttuuriministeriö (2010). Kulttuurialan kolmas sektori. Opetus- ja kulttuuriministeriön julkaisuja 2010: 24. Helsinki: Opetus- ja kulttuuriministeriö. http://www.minedu.fi/export/ sites/default/OPM/Julkaisut/2010/liitteet/OKM24.pdf (4.10.2016).

Paloniemi, S. (2004). Ikä, kokemus ja osaaminen työelämässä. Työntekijöiden käsityksiä iän ja kokemuksen merkityksestä ammatillisessa osaamisessa ja sen kehittämisessä. Jyväskylä studies in education psychology and social research 253. Jyväskylä: Jyväskylän yliopisto.

Pihlaja, R. (2010). Kolmas sektori maaseutukunnissa. Ruralia-instuutin julkaisuja 19. Helsinki: Helsingin yliopisto.

Pärnänen. A. \& Sutela, H. (2011). Työn tekemisen uudet muodot ja tilastot. Hyvinvointikatsaus 4. Helsinki: Tilastokeskus.

Ruuskanen, P., Selander, K. \& Anttila, T. (2013). Palkkatyössä kolmannella sektorilla. Julkaisuja 19. Helsinki: Työ- ja elinkeinoministeriö.
Selander, K. (2015). Work engagement in the third sector. Voluntas: International Journal of Voluntary and Nonprofit Organizations 26 (4), 1391-1411.

Selander, K., Ruuskanen, P. \& Anttila, T. (2012). Työn ja perheen ristiriidat kolmannen sektorin palkkatyössä. Työelämän tutkimus 3, 209-227.

Siisiäinen, M. (2002) Yhdistyslaitoksen yleiskuva Jyväskylässä. Teoksessa M. Siisiäinen (toim.), Yhdistykset kolmannen sektorin toimijoina: tutkimus jyväskyläläisistä yhdistyksistä. Helsinki: Sosiaali- ja terveysturvan keskusliitto.

Smith, H. L. (2014). Triple-loop reflective learning within non-Governmental health organizations in Sub-Saharan Africa: An organizational learning perspective. Proceedings of the Fourth International Conference on Engaged Management Scholarship, Tulsa, OK, USA, 10.-14.10.2014. (4.2.2017).

Sutela, H. (2013). Määräaikainen työ ja perheellistyminen Suomessa 1984-2008. Tutkimuksia 259. Helsinki: Tilastokeskus.

Wenger, E. (2000). Communities of practice and social learning system. Organization 7(2), 225-246. 